Arq. Bras. Med. Vet. Zootec., v.62, n.4, p.812-815, 2010

\title{
Mammary carcinosarcoma in cat: a case report
}

[Carcinossarcoma mamário em gata: relato de Caso]

J.D.G. Paniago, A.L.S. Vieira, N.M. Ocarino, S.A. França, C. Malm, G.D. Cassali, R. Serakides*

Universidade Federal de Minas Gerais

Avenida Presidente Antônio Carlos, 6627

31270-901 - Belo Horizonte, MG

\begin{abstract}
A case of mammary carcinosarcoma is reported in a 13-year-old, mixed breed female cat, which was not spayed and had not received contraceptives. The patient presented extensive and coalescent nodules in all mammary glands. Based on the histological and immunohistochemical findings, the diagnosis of mammary carcinosarcoma was confirmed.
\end{abstract}

Keywords: cat, carcinosarcoma, mammary gland

\section{RESUMO}

Descreve-se um caso de carcinossarcoma mamário em uma gata, sem raça definida, de 13 anos de idade. A gata não era castrada e não recebeu anticoncepcionais. A paciente apresentou extensivos $e$ coalescentes nódulos em todas as glândulas mamárias. Com base nos achados histológicos e imunoistoquímicos, firmou-se o diagnóstico de carcinossarcoma da glândula mamária.

Palavras-chave: gato, carcinossarcoma, glândula mamária

\section{INTRODUCTION}

In cats, the mammary neoplasias are the third most frequent, after the cutaneous tumors and the lymphoma. Among the neoplasias in felines, the mammary tumors represent $12 \%$ of them (Misdorp and van der Heul, 2002), and the mammary carcinoma is the tumor type most commonly found in cats (Johnson, 1994; Misdorp and van der Heul, 2002; Amorim et al., 2006) and felids (McAloose et al., 2007). The mammary carcinosarcoma is rare in felines (Fusaro et al., 2009), and also occurs with low frequency in dogs (Sanchez et al., 2005; Pliego et al., 2008). The carcinosarcoma is a neoplasia composed of cells morphologically resembling malignant epithelial components and cells resembling malignant connective tissue elements (Misdorp et al., 1999; Misdorp and van der Heul, 2002; Sanchez et al., 2005).

In spite of the rarity in felines, the carcinosarcoma should always be considered in the different diagnoses of the mammary neoplasias, especially those of undifferentiated neoplasias. To correctly recognize this tumor type, their histological and immunohistochemical characteristics are important. The objective of this paper is to describe a case of mammary carcinosarcoma in a cat.

\section{CASE REPORT}

A 13-year-old mixed breed female cat was admitted to a Veterinary Teaching Hospital with a history of mammary nodules. The cat was not spayed and did not receive contraceptives. At clinical examination, the patient presented extensive and coalescent nodules in all of the mammary glands. Thoracic $\mathrm{x}$-rays were performed to verify possible pulmonary metastasis. Due to metastasis absence, complete mastectomy was performed. Tissue samples of the tumor were fixed in $10 \%$ neutral buffered formalin, embedded in paraffin, cut at $5 \mu \mathrm{m}$, and stained with hematoxylin and eosin. To establish

Recebido em 12 de agosto de 2009

Aceito em 12 de julho de 2010

Autor para correspondência (corresponding author)

E-mail: serakide@dedalus.lcc.ufmg.br 
a final diagnosis of the neoplasm, immnohistochemical analysis was done and the following antibodies were applied in appropriate dilutions: anticytokeratin 1:50 (clone 35 Dako) and antivimentin 1:100 (clone V9 Dako). The streptavidin-biotin-peroxidase complex (Dako) and diaminobenzidin (Sigma Chemical Co., St. Louis, MO) were used as the detection system. Sections were counterstained with Harris' hematoxylin. Positive and negative controls were made to ensure the accuracy of the results. The negative control was the tumoral tissue incubated with phosphate-buffered saline (PBS) in substitution of the primary antibodies.

Microscopically, the neoplasm had infiltrative growth with a solid pattern and was composed of a heterogeneous cell population, mainly pleomorphics (Figure 1a). Polyhedral cells showing ovoid or vesicular nuclei with prominent nucleoli and abundant lightly acidophilic cytoplasm resembling epithelial cells were observed. Cells with scant cytoplasm and elongated or oval nuclei containing
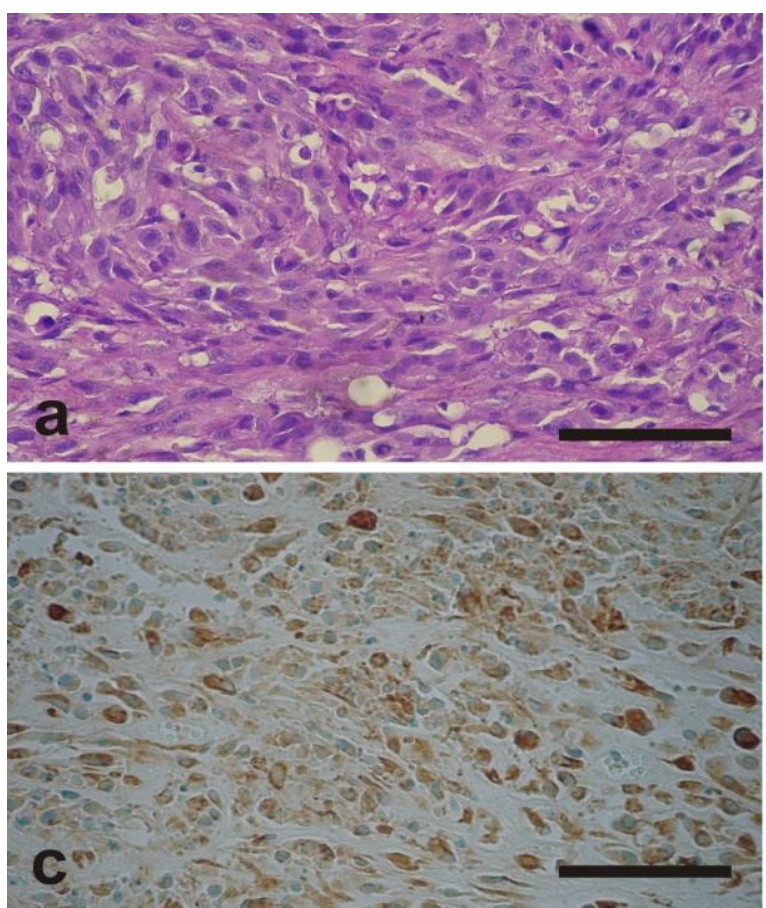

Figure 1. a) Microscopic appearance of the mammary mass revealing a malignant tumor with a biphasic pattern of epithelial and mesenchymal components. (HE, Bar= 46 $\mu \mathrm{m})$. b) Mammary carcinosarcoma, cat. Strong and diffuse labeling for cytokeratin in the cytoplasm of the neoplastic cells. Streptavidin-biotin-peroxidase method, Harris haematoxylin counterstain. $\mathrm{Bar}=46 \mu \mathrm{m}$. c) Mammary carcinosarcoma, cat. Strong and diffuse labeling for vimentin in the cytoplasm of the neoplastic cells. Streptavidin-biotin-peroxidase method, Harris haematoxylin counterstain. Bar $=46 \mu \mathrm{m}$. d) Laterolateral plain radiograph of the thoracic cavity of a 13-year-old, mixed breed female cat after mastectomy. Presence of radiodense areas suggestive of metastasis. 
At necropsy, a multilobulated ulcerated mass and infiltration were observed in the chirurgic area. The mass infiltrated into the skin, subcutaneously and adjacent to the musculature. The neoplasia was solid, firm, and red-brownish. Inside, the thoracic cavity had a large amount of transuded fluids. The lungs presented several solid, firm, and red-brownish nodules of approximately $3 \mathrm{~cm}$. Tissue samples of the tumor and the lungs were fixed in $10 \%$ neutral buffered formalin, embedded in paraffin, cut at $5 \mu \mathrm{m}$, and stained with hematoxylin and eosin for histological analysis. In addition, immnohistochemical analysis was done with the following antibodies applied in appropriate dilutions: anticytokeratin 1:50 (clone 35 Dako) and antivimentin (clone V9 Dako). The histological and immunohistochemical patterns were similar to the mammary neoplasia removed in the mastectomy, so the recurrence and the metastasis diagnosis were confirmed.

Tissue samples were collected from select organs (heart, kidney, liver, spleen, and brain), embedded in paraffin, sectioned and then stained with haematoxylin and eosin. All organs showed normal histological characteristics.

\section{DISCUSSION}

The carcinosarcoma is a neoplasia characterized as containing a mixed cell population with malignant proliferation of both mesenchymal and epithelial-like cells (Sanchez et al., 2005). Although the carcinosarcomas are rare in the domestic species, their origin has been discussed in two theories: 1) multiclonal theory suggests that the epithelial and the mesenchymal components originated from two or more stem cells; 2) the monoclonal theory suggests that the epithelial and the mesenchymal components originated from totipotential neoplastic cells play multiple potential pathways of terminal differentiation (Sánchez et al., 2005).

In spite of being rare in felines, the carcinosarcoma should always be considered in the different diagnoses of the mammary neoplasias, mainly of those undifferentiated neoplasias. Invariably, the histological analysis is insufficient to determine the diagnosis. It needs immunohistochemical analysis to verify the coexpression of the vimentin and cytokeratin in the neoplastic cells. In this study, similar to results described in canines (Sanchez et al., 2005), the positive immunolabeling for the anticytokeratin and anti-vimentin antibodies confirmed the presence of the carcinomatous and the sarcomatous areas, respectively, and corroborated the histological findings. Although infrequent, some carcinosarcomas can present differentiated mesenchymal tissue, for example, areas of differentiated chondroid, osteoid, or adipose tissue (Tokodume et al., 2005). In these cases, the main different diagnoses are the primary sarcomas of the mammary gland including osteosarcomas, chondrosarcomas, liposarcomas, and fibrosarcomas (Ginn et al., 2007).

\section{REFERENCES}

AMORIM, F.V.; SOUZA, H.J.M.; FERREIRA, A.M.R. et al. Clinical, cytological and histopathological evaluation of mammary masses in cats from Rio de Janeiro, Brazil. J. Feline Med. Surg., v.8, p.379-388, 2006.

FUSARO, L.; PANARESE, S.; BRUNETTI, B. et al. Quantitative analysis of telomerase in feline mammary tissues. J. Vet. Diagn. Invest., v.21, 369-373, 2009.

GINN, P.E.; MANSELL, J.E.K.L.; RAKICH, P.M. Skin and appendages. In: MAXIE, M.G. (Ed). Jubb, Kennedy and Palmer's pathology of domestic animals. 5.ed. Philadelphia: Saunders Elsevier, 2007. v.1, p.551-781.

JOHNSON, C.A. Female reproduction and disorders of the female reproductive tract. In: SHERDING, R.G. (Ed). Cat: diseases and clinical management. 2.ed. Philadelphia: W.B. Saunders, 1994. p.1874-1875.

McALOOSE, D.; MUNSON, L.; NAYDAN, D.K. Histologic features of mammary carcinomas in zoo felids treated with melengestrol acetate (MGA) contraceptives. Vet Pathol., v.44, p.320-326, 2007.

MISDORP, W.; ELSE, W.; HELLMEN, E. et al. Histological classification of the mammary tumors of the dog and the cat. In: WORLD Health Organization International Histological of Tumors of Domestic Animals. 2.ed., Washington, DC: Armed Forces Institute of Pathology, American Registry of Pathology, 1999. 
MISDORP, W.; van der HEUL, R.O. Carcinosarcomas of the dogs. Vet. Pathol., v.17, p.53-57, 2002.

PLIEGO, C.M.; FERREIRA， M.L.G.; FERREIRA, A.M.R. et al. Diagnostic quality of mammary nodes biopsy with Super-core II $^{\circledR}$ needle of bitches. Cienc. Rural, v.38, p.22032209, 2008.
SANCHEZ, J.; BUENDÍA, A.J.; VILAFRANCA, $M$. et al. Canines carcinosarcomas in the head. Vet. Pathol., v.42, p.828-838, 2005.

TOKODUME, N.; SAKAMOTO, G.; SAKAI, T. et al. A case of carcinosarcoma of the breast. Breast Cancer, v.12, p.149-153, 2005. 